\title{
Causes of stillbirth according to different gestational ages
}

\author{
Aditi Jindal*, Rama Thakur, Santosh Minhas
}

Department of Obstetrics and Gynecology, Indira Gandhi Medical College, Shimla, Himachal Pradesh, India

Received: 01 January 2018

Accepted: 31 January 2018

\section{*Correspondence:}

Dr. Aditi Jindal,

E-mail: aditijindal_18@yahoo.com

Copyright: (C) the author(s), publisher and licensee Medip Academy. This is an open-access article distributed under the terms of the Creative Commons Attribution Non-Commercial License, which permits unrestricted non-commercial use, distribution, and reproduction in any medium, provided the original work is properly cited.

\section{ABSTRACT}

Background: Stillbirth is one of the most common yet the most poorly studied adverse outcome of pregnancy. Objective of present study was to determine the risk factors and prevalence of stillbirth at Department of Obstetrics and Gynecology, Kamla Nehru State Hospital, for Mother and Child, Indira Gandhi Medical College, Shimla, Himachal Pradesh.

Methods: A prospective non-interventional study was conducted with effect from $1^{\text {st }}$ August 2015 to $31^{\text {st }}$ July 2016 , during which all the intrapartum and antepartum stillbirths were enrolled.

Results: During the study period total number of stillbirth were 94 and the total number of live births were 6412 , giving a stillbirth rate of $14.66 / 1000$ live births. The perinatal mortality was $22.1 / 1000$ births. The most common cause of stillbirth as revealed in the study was hypertensive disorder.

Conclusions: The stillbirth rate in the study was higher than the stillbirth rate of developed countries. Improvement of socioeconomic conditions, literacy and health education among women will definitely be important to curb the staggeringly high stillbirth rate, but the need of the hour is to deploy adequate number of dedicated skilled providers.

Keywords: Hypertensive disorders, Perinatal mortality rate, Stillbirth rate

\section{INTRODUCTION}

Stillbirth is one of the most common yet the most poorly studied adverse outcome of pregnancy. ${ }^{1}$ It is a devastating experience for both obstetrician and the patient. WHO defines stillbirth as fetal death late in pregnancy allowing each country to define gestational age at which fetal death is considered stillbirth. ${ }^{2}$

Fetus without signs of life i.e, Apgar 0-0-0 when delivered is stillborn. ${ }^{3}$ American College of Obstetrics and Gynecology refers Intrauterine fetal demise as the demise occurring at or later than 20 weeks.

Stillbirth is a relatively understudied major health issue and has not been accounted for globally as a part of major maternal and child health strategies. ${ }^{4}$ A substantial proportion of fetal deaths are still classified as unexplained intrauterine fetal demise. In general, the study of specific causes of stillbirth has been affected by scarcity of uniform protocols for assessment and classification of stillbirths and falling autopsy rates.

There exists no standard intervention/ classification system that defines causes of fetal death making comparisons of cause of stillbirth and rate over time and between sites problematic. For many reasons, stillbirths have been under reported and rarely have been considered in attempts to improve adverse pregnancy outcome in developing countries. ${ }^{5}$

It is estimated that some 1.8 million stillbirths occur in 10 countries including India. ${ }^{6}$ Stillbirths vary sharply with country, ranging from $2 / 1000$ total births in Finland to more than 40/1000 total births in Nigeria and Pakistan. ${ }^{1}$ Current stillbirth rate in India is $22 / 1000$ live births. 
Approximately $45 \%$ occur intrapartum reflecting a lack of skilled birth attendants and emerging obstetric care. Perinatal mortality reflects one of the important health indices of country and it is one of the sensitive indicators of maternal and child health care. ${ }^{5}$

Stillbirth in India differs from state to state ranging from 01 to $14 / 1000$, with the highest rate of stillbirth occurring in Karnataka and lowest being in Jharkhand, probably due to gross underreporting from Jharkhand. The rate of stillbirth in Himachal Pradesh is 10/1000 live births as per Himachal Pradesh Demographics reported in 2010 . $^{7}$ According to India Newborn Action Plan, India used the estimates provided by Lancet stillbirth rate of 25/1000 birth in 1995 . With the current level of average annual rate which is less than $1 \%$. India would reach single digit stillbirth rate by 2010 , with all the states to individually achieve this target by 2035 .

Studying ethology of stillbirth is very crucial if further improvements are to be made. Many times these mortalities are due to preventable causes. The most common cause of perinatal mortality continues to be congenital malformations, accounting for $25-40 \%$ of the cases. ${ }^{8}$ The identification of at risk population may enable design of targeted antepartum testing regimens to improve outcome. ${ }^{9}$

Determining the cause of fetal death aids maternal psychological adaptation to a significant loss and may prompt therapy or intervention to prevent a similar outcome in the next pregnancy. ${ }^{10}$ Detection of causes of stillbirths is important to identify deficiencies in the provision of care, to focus attention on areas in which improvements are possible, and to indicate areas in which new developments or knowledge may be expected to lead to preventive measures to lower the perinatal mortality. ${ }^{11}$

For women at increased risk of stillbirth due to other causes, such as hypertension and diabetes, antepartum surveillance has been widely integrated into clinical practice, despite a dearth of evidence from few randomised control trials. ${ }^{12}$

The illumination of perinatal health issues is interesting because some reproductive outcomes are associated with both the degree of social deprivation and the quality of care. ${ }^{13}$ Late fetal and intraapartum deaths are strongly related to both health care and social context. Stillbirth rates can be used as an indicator of perinatal care quality. Thorough investigation of each individual stillbirth case, by means of an integrated study protocol, along with the pathologist's close collaboration, allows identification of a likely cause in the majority of cases.

Objectives of present study were to determine the prevalence of stillbirth and to assess the magnitude of problem at Kamla Nehru State Hospital, for Mother and Child, Indira Gandhi Medical College, Shimla, to ascertain the risk factors and causes of stillbirth and to recommend remedial measures to be adopted in an attempt to reduce stillbirth rate in our facility.

\section{METHODS}

A prospective non-interventional observational study was conducted with effect from 1st August 2015 to 31st July 2016 at Kamla Nehru State Hospital for Mother and Child, Indira Gandhi Medical College, Shimla. During the study period, all the antepartum and intrapartum stillbirths were enrolled.

\section{Inclusion criteria}

- All the subjects regardless of their booking status who delivered stillborn in this hospital were included in this study.

- $\quad$ Stillbirth at $>20$ weeks (if gestational age was known), or weight $\geq 500$ gm (if gestational age was not known) were included in the study.

- Both singleton and multiple pregnancies were included in the study.

\section{Exclusion criteria}

Women diagnoses with Intrauterine demise but planning to deliver outside were excluded from the study.

Gestational age was estimated by: First day of last menstrual period when reliable and/or early USG imaging before 20 weeks of gestation. Demographic data, age, parity, level of literacy, socioeconomic status, booking status were noted.

Detailed history was taken regarding various obstetric risk factors in current pregnancy. This was followed by general physical examination, BMI calculation and systemic examination. Apart from routine investigations of pregnancy, the following specific investigations were done in order to find out the ethology of intrauterine/intrapartum fetal death:

- Suspected hypertension related disease: Complete hemogram, renal function test with uric acid levels, liver function test, urine albumin, 24-hour urinary protein, fundus.

- Suspected diabetes-related disease, macrosomia (history), a strong family history of diabetes, or obesity: HbA1c, Blood Sugar Profile.

- Suspected fetal hydrops: antibody screening, parvovirus B19 serology, Rh status and ICT in Rh incompatibility and haemoglobin electrophoresis.

- Suspected chorioamnionitis: Total leukocyte count (TLC), Differential leukocyte count (DLC), Creactive protein (CRP), vaginal swab $\mathrm{c} / \mathrm{s}$ and placental membranes were sent for culture and Histopathological examination.

- IUFD with fever: septic screen i.e TLC, CRP, slide for malarial parasite, Widal test, Weil Felix, Urine microscopic examination and culture, Endocervical 
swab for culture and sensitivity, Placental membrane for culture and sensitivity.

- Coagulogram and platelet count to rule out coagulopathy.

Written informed consent for labor was taken. As no pathological autopsies are being done at Indira Gandhi Medical College, following delivery stillborn placentae were examined thoroughly. Placentae along with umbilical cord and membranes were sent in a sterile tissue culture medium of lactated Ringer's solution when transported to the laboratory for pathological examination. A part of fetal membranes was sent for culture and sensitivity.

\section{Statistical analysis}

Significance of difference was analysed using unpaired student $\mathrm{t}$ test. Statistical analysis was done using statistical software Epi info version 7.

\section{RESULTS}

During the study period total number of stillbirth were 94 and the total number of live births were 6412 , giving a stillbirth rate of $14.66 / 1000$ live births. The perinatal mortality rate was $22.1 / 1000$ births (Table 1 ).

Table 1: Stillbirth and perinatal mortality.

\begin{tabular}{|ll|}
\hline Total deliveries & 6412 \\
\hline Total number of stillbirth & 94 \\
\hline Stillbirth rate & $14.66 / 1000$ live births \\
\hline Perinatal death & 144 \\
\hline Perinatal mortality rate & $22.1 / 1000$ births \\
\hline Fresh stillbirth & 44 \\
\hline Macerated stillbirth & 50 \\
\hline
\end{tabular}

Table 2 shows that the maximum number of stillbirth $(76.59 \%)$ were in women between age group 20-30 years. $65.97 \%$ women were unbooked, $67.07 \%$ belonged to rural area. $55.3 \%$ belonged to lower middle class.

$47.87 \%$ stillbirth were in obese women. $64.89 \%$ stillbirths were among primigravidae. $36.17 \%$ women had to travel $>50-150$ kilometres to reach the hospital.

$35.1 \%$ had still birth at term. Among the total $88.64 \%$ delivered vaginally. One cesarean section was done for acute fetal distress. Three exploratory laparotomy were done for rupture uterus.

Table 3 shows that $63.8 \%$ stillborn were male. $31.91 \%$ were small for gestational age.

Table 4 depicts that $31.91 \%$ placentae had subchorionic hematoma. $26.59 \%$ placentae on histopathological examination revealed acute chorioamnionitis. $42.55 \%$ had evidence of subclinical chorioamnionitis. Most common organism responsible was Escherechia coli.

Table 2: Maternal characteristics ( $n=94)$.

\begin{tabular}{|c|c|c|}
\hline & $\begin{array}{l}\text { Number of } \\
\text { stillbirth }\end{array}$ & Percentage \\
\hline \multicolumn{3}{|l|}{ Age } \\
\hline$<20$ years & 8 & 8.5 \\
\hline 20 - 30 years & 72 & 76.59 \\
\hline$>30$ years & 14 & 14.89 \\
\hline \multicolumn{3}{|l|}{ Booking status } \\
\hline Unbooked & 62 & 65.97 \\
\hline Booked at $\mathrm{KNH}$ & 18 & 19.14 \\
\hline Booked elsewhere & 14 & 14.89 \\
\hline \multicolumn{3}{|l|}{ Maternal residence } \\
\hline Rural & 63 & 67.07 \\
\hline Urban & 31 & 32.93 \\
\hline \multicolumn{3}{|l|}{ Socioeconomic status } \\
\hline Upper & 7 & 7.4 \\
\hline Upper Middle & 27 & 28.72 \\
\hline Lower Middle & 52 & 55.3 \\
\hline Upper Lower & 5 & 5.3 \\
\hline Lower & 3 & 3.19 \\
\hline \multicolumn{3}{|l|}{ Body mass index } \\
\hline$<18.5$ (underweight) & 35 & 37.23 \\
\hline 18.5-24.99 (Normal) & 9 & 9.57 \\
\hline 25-30(overweight) & 45 & 47.87 \\
\hline$>30$ (obese) & 5 & 5.31 \\
\hline \multicolumn{3}{|l|}{ Gravidity } \\
\hline Primigravida & 61 & 64.89 \\
\hline Multigravida & 33 & 35.11 \\
\hline \multicolumn{3}{|c|}{ Prior history of stillbirth } \\
\hline None & 86 & 91.49 \\
\hline One & 5 & 5.32 \\
\hline Two & 2 & 2.12 \\
\hline Three & 1 & 1.06 \\
\hline \multicolumn{3}{|c|}{ Distance travelled to reach hospital } \\
\hline upto $15 \mathrm{~km}$ & 9 & 9.5 \\
\hline$>15-50 \mathrm{~km}$ & 20 & 21.27 \\
\hline$>50-150 \mathrm{~km}$ & 34 & 36.17 \\
\hline$>150 \mathrm{~km}$ & 31 & 32.97 \\
\hline \multicolumn{3}{|c|}{ Period of gestation at birth } \\
\hline$<28$ weeks & 20 & 21.2 \\
\hline $28+0$ to $33+6$ weeks & 21 & 22.34 \\
\hline $34+0$ to $36+6$ weeks & 16 & 17.02 \\
\hline $37+0$ to $41+6$ weeks & 33 & 35.1 \\
\hline$>42$ weeks & 4 & 4.25 \\
\hline \multicolumn{3}{|l|}{ Mode of delivery } \\
\hline Vaginal delivery & 39 & 88.64 \\
\hline $\begin{array}{l}\text { Instrumental vaginal } \\
\text { delivery }\end{array}$ & 1 & 2.27 \\
\hline Caesarean Section & 1 & 2.27 \\
\hline Exploratory Laprotomy & 3 & 6.81 \\
\hline
\end{tabular}

Table 5 depicts hypertensive disorders as the most common cause of stillbirth. 
Table 3: Fetal characteristics $(n=94)$.

\begin{tabular}{|lll|}
\hline Sex of stillborn & Number & Percentage \\
\hline Male & 60 & 63.8 \\
\hline Female & 34 & 36.2 \\
\hline Birth weight & & \\
\hline $\begin{array}{l}\text { Appropriate for gestational } \\
\text { age }\end{array}$ & 62 & 65.95 \\
\hline Small for gestational age & 30 & 31.91 \\
\hline Large for gestational age & 2 & 2.12 \\
\hline
\end{tabular}

Table 4: Placental characteristics $(n=94)$.

\begin{tabular}{|c|c|c|}
\hline & Number & Percentage \\
\hline \multicolumn{3}{|c|}{ Gross placental examination } \\
\hline Subchorionic hematoma & 30 & 31.91 \\
\hline Necrosis & 24 & 25.5 \\
\hline Normal & 40 & 41.59 \\
\hline \multicolumn{3}{|c|}{ Histopathological placental examination } \\
\hline Infarcted chorionic villi & 10 & 10.63 \\
\hline Thrombotic vasculopathy & 8 & 8.5 \\
\hline Acute funisitis & 13 & 13.82 \\
\hline Acute chorioamnionitis & 25 & 26.59 \\
\hline None & 38 & 40.45 \\
\hline \multicolumn{3}{|l|}{ Membrane culture } \\
\hline Negative & 54 & 57.45 \\
\hline Positive & 40 & 42.55 \\
\hline
\end{tabular}

Table 5: Probable cause of stillbirth.

\begin{tabular}{|lll|}
\hline Hypertensive disorder & 25 & 26.6 \\
\hline $\begin{array}{l}\text { Hyperglycemia in } \\
\text { pregnancy }\end{array}$ & 8 & 8.5 \\
\hline Congenital anomalies & 12 & 12.7 \\
\hline Cord accidents & 3 & 3.1 \\
\hline $\begin{array}{l}\text { Severe Intrauterine growth } \\
\text { restriction }\end{array}$ & 8 & 8.5 \\
\hline Antepartum haemorrhage & 6 & 6.3 \\
\hline Jaundice in pregnancy & 7 & 7.4 \\
\hline Rupture uterus & 3 & 3.1 \\
\hline Head entrapment & 2 & 2.1 \\
\hline Non-immune fetal hydrops & 3 & 3.1 \\
\hline Peripartum asphyxia & 3 & 3.1 \\
\hline Maternal Infections & 3 & 3.1 \\
\hline Unexplained & 11 & 11.7 \\
\hline
\end{tabular}

Table 6 depicts the cause of stillbirth at different gestational ages. The most common cause of death in preterm stillborn was hypertensive disorder.

In term stillborns the most common cause of stillbirth was APH.

In postterm stillborns $50 \%$ were due to hypertensive disorders and another $50 \%$ due to hyperglycaemia in pregnancy.
Table 6: Probable cause of stillbirth at different gestational ages.

\begin{tabular}{|c|c|c|c|}
\hline Causes & Preterm & Term & $\begin{array}{l}\text { Post- } \\
\text { term }\end{array}$ \\
\hline $\begin{array}{l}\text { Hypertensive } \\
\text { disorder }\end{array}$ & $\begin{array}{l}19 \\
(33.33 \%)\end{array}$ & $\begin{array}{l}4 \\
(12.12 \%)\end{array}$ & $2(50 \%)$ \\
\hline $\begin{array}{l}\text { Hyperglycemia in } \\
\text { pregnancy }\end{array}$ & $2(3.6 \%)$ & 4 & $2(50 \%)$ \\
\hline $\begin{array}{l}\text { Congenital } \\
\text { anomalies }\end{array}$ & $\begin{array}{l}10 \\
(17.85 \%)\end{array}$ & $\begin{array}{l}2 \\
(6.06 \%)\end{array}$ & 0 \\
\hline Cord accidents & $1(1.8 \%)$ & $\begin{array}{l}2 \\
(6.06 \%)\end{array}$ & 0 \\
\hline $\begin{array}{l}\text { Severe Intrauterine } \\
\text { growth restriction }\end{array}$ & $\begin{array}{l}3 \\
(5.35 \%)\end{array}$ & $\begin{array}{l}5 \\
(15.15 \%)\end{array}$ & 0 \\
\hline $\begin{array}{l}\text { Antepartum } \\
\text { haemorrhage }\end{array}$ & $1(1.8 \%)$ & $\begin{array}{l}6 \\
(18.18 \%)\end{array}$ & 0 \\
\hline $\begin{array}{l}\text { Jaundice in } \\
\text { pregnancy }\end{array}$ & $\begin{array}{l}3 \\
(5.35 \%)\end{array}$ & $(12.12 \%)$ & 0 \\
\hline Rupture uterus & $2(3.6 \%)$ & $\begin{array}{l}1 \\
(3.03 \%)\end{array}$ & 0 \\
\hline Head entrapment & $1(1.8 \%)$ & $\begin{array}{l}2 \\
(6.06 \%)\end{array}$ & 0 \\
\hline $\begin{array}{l}\text { Non-immune fetal } \\
\text { hydrops }\end{array}$ & $\begin{array}{l}3 \\
(5.35 \%)\end{array}$ & 0 & 0 \\
\hline $\begin{array}{l}\text { Peripartum } \\
\text { asphyxia }\end{array}$ & 0 & $\begin{array}{l}3 \\
(9.09 \%)\end{array}$ & 0 \\
\hline Maternal Infections & 0 & $\begin{array}{l}4 \\
(12.12 \%)\end{array}$ & 0 \\
\hline Unexplained & $\begin{array}{l}11 \\
(19.64 \%)\end{array}$ & 0 & 0 \\
\hline
\end{tabular}

\section{DISCUSSION}

The stillbirth rate in the current study was 14.66/1000 live births which was comparable to the stillbirth rate in a study by Mustafa et al (18/1000 liver births) but was much lower than the study by Choudhary et all (49/1000 live births). ${ }^{14,15}$ This could be due to a higher female literacy rate in our state i.e. $76.6 \%$ which is $2^{\text {nd }}$ highest in the country, better socioeconomic conditions, better antenatal care, free antenatal services and delivery, free 108 and 102 ambulance services.

One risk factor that has received considerable attention to identify at risk group of stillbirths is maternal age. One possible explanation in teenage pregnancy in several population-based studies could be finding that teenage mother are more likely to come from a disadvantaged background which is itself a high risk for stillbirth. On the contrary advanced maternal age is associated with more medical complications.

$65 \%$ of the women were not booked in our study which is comparable to that studied by Bhattacharya et al where only $29.71 \%$ were booked. ${ }^{5}$ A high percentage of unbooked cases could be due to poverty, ignorance, illiteracy, poor support from family and poor transport 
system which in turn is responsible for suboptimal care by non-utilization of antenatal care.

Maximum number of patients $(54.25 \%)$ were overweight or obese. Obesity increases the risk of gestational diabetes mellitus and hypertensive disorders, both of which are established risk factors for stillbirths. ${ }^{16,17}$

In present study stillborns were male more than female. This is due to much higher expression of genes involved in placental development, the maintenance of pregnancy, and maternal immune tolerance with female foetuses. Male foetuses also grow faster than female foetuses, from the moment of conception.

The most common cause of preterm, term and postterm stillbirth in our study was hypertensive disorder, antepartum haemorrhage and hypertensive disorder along with diabetes respectively. On the other hand, Bring HS et $\mathrm{al}^{3}$ observed that the most common cause of preterm stillbirth was hypertensive disorder, of term stillbirth was IUGR and poster stillbirth was infection.

\section{CONCLUSION}

The stillbirth rate in the current study was 14.66/1000 live births which is lower than the national average (22/1000 live births) but higher than the stillbirth rate of developed countries. Improvement of socioeconomic conditions, literacy and health education among women will definitely be important to curb the staggeringly high stillbirth rate, but the need of the hour is to deploy adequate number of dedicated skilled providers. Widespread Information, education and communication activities about the various ongoing Government Health Programmes, including JSY (Janani Suraksha Yojana) etc is required, so that more and more women come into the health care net.

Unfortunately, pathological autopsy was not available in our institution, so the cause of stillbirth was based on history and clinical judgement. It is recommended that facility of pathological autopsy should be made available to know the definite cause of stillbirth in all institutions.

The lower stillbirth rate as compared to the national average could be attributed to the fact that the study was conducted in a tertiary care centre and the population studied was non-homogenous. An epidemiological study representing the entire obstetric population is recommended to know the exact scenario.

Limitations of present study are:

Present study was conducted over a short period of one year, with limited study population. In an effort to study this issue better a large sample that accurately reflects the entire obstetric population needs to be studied.
The stillbirth rate reflected in the study may not be the actual stillbirth rate since only institutional deliveries were included in the study and home deliveries were not included in the study.

Pathological autopsy could not be performed, which may have altered the true causes of stillbirth.

Funding: No funding sources

Conflict of interest: None declared

Ethical approval: Not required

\section{REFERENCES}

1. Mondal D, Galloway TS, Bailey TC, Mathews F. Elevated risk of still birth in males: systematic review and meta-analysis of more than 30 million births. BMC Medicine. 2014;12(220):1741-55.

2. Robalo R, Pedroso C, Amaral N, Soares C. Late Stillbirth: a ten year cohort study. Acts Med Port. 2013;26(1):39-42.

3. Bring HS, Varli IAH, Kublickas M, Papadogiannakis $\mathrm{N}$, Petersson K. Causes of stillbirth at different gestational ages in singleton pregnancies. Acta Obstet Gynecol Scand. 2014 Jan;93(1): 86-92.

4. Gordon A, Greenow C R, McGeechan K, Morris J, Jeffery H. Risk factors for antepartum stillbirth and the influence of maternal age in New South Wales Australia: A population based study. BMC Pregnancy Childbirth. 2013;13(12):1471-81.

5. Bhattacharya S, Mukhopadhya G, Mistry P K, Pati S, Saha SP. Stillbirth in a tertiary care Referral Hospital in North Bengal: a review of causes, risk factors and prevention strategies, Online J Health Allied Sci. 2010;9(4):4.

6. Avachat SS, Phalke DB, Phalke VD. Risk factors associated with stillbirths in the rural areas of Western Maharashtra, India. Arch Med Health Sci. 2015;2(3):56-59.

7. Bhati DK. Stillbirths: A high magnitude public health issue in India. South East Asia J Public Health. 2013;3(1):3-9.

8. Nayak SR, Garg N. Determinants of antepartum fetal death. J Obstet Gynecol India. 2010;60(6): 494-97.

9. Vergani P, Cozzolino S, Pozzi E, Cuttin MS, Greco $\mathrm{M}$, Ornaghi $\mathrm{S}$ et al. Identifying the causes of stillbirth: a comparison of four classification systems. Am J Obstet Gynecol. 2008;199(31):1-4.

10. Fox NS, Rebarber A, Silverstein M, Roman AS, Klauser CK, Saltzman DH. The effectiveness of antepartum surveillance in reducing the risk of stillbirth in patients with advanced maternal age. Euro J Obstet Gynecol Reprod Biol. 2013;170(13):387-90.

11. Reime B, Lindwedel U, Ertl KM, Jacob C, Schücking B, Wenzlaff P. Does under utilisation of prenatal care explain the excess risk for stillbirth among women with migration background in Germany. Acta Obstetricia et Gynecologia. 2009;88(10):1276-83. 
12. Saastad E, Vangen S, Froen F. Suboptimal care in stillbirths- a retrospective audit study. Acts Obsetricia et Gynecologia. 2007;86(9):444-50.

13. Lehra MM, Gordon A, Jeffery HE. Chorioamniotis and fetal response in stillbirth. Am J Obstet Gynecol. 2007;196(229):1-4.

14. Mustufa MA. Frequency of stillbirths in a Tertiary care hospital of Karachi. Pak J Med Sci. 2016;32(1):91-4.

15. Choudhary A, Gupta V: Epidemiology of intrauterine fetal deaths: a study in tertiary care referral centre in Uttarakhand. IOSR-JDMS. 2014;13(3):3-6.
16. Fretts RC. Etiology and prevention of stillbirth. Am J Obstet Gynecol. 2005;193(4):1923-35.

17. Goldenberg RL, Kirby R, Culhane JF. Stillbirth: a review. J Matern Fetal Neonatal Med. 2004;16(3):79-94.

Cite this article as: Jindal A, Thakur R, Minhas $\mathrm{S}$. Causes of stillbirth according to different gestational ages. Int J Reprod Contracept Obstet Gynecol 2018;7:1029-34. 